\title{
1. Introduction to Global Jihadist Terrorism
}

\author{
Paul Burke, Doaa' Elnakhala and Seumas \\ Miller
}

Since the attacks of 11 September 2001 by al-Qaeda (AQ) operatives, countering jihadist terrorism has become a primary security and political priority for many liberal democracies. The fact that global jihadist terrorism, notably in the form of AQ, Islamic State (IS) and their affiliates, has affected other liberal democratic regimes only deepens these concerns. Consequently, we have seen considerable shifts in the counter-terrorism (CT) strategies and tactics of liberal democracies, and in respect of their legal and other institutional arrangements concerned with security. Of course, jihadist terrorism has not only affected liberal democracies but more often than not it has also had greater direct impact on authoritarian states or, at least, on states other than well-ordered liberal democracies, such as Iraq, Syria, Afghanistan and Pakistan. Given their global ambitions and reach, the terrorist operations conducted by AQ, IS and their affiliates still impact upon liberal democracies both directly and indirectly. Such liberal democracies are the focus of both this volume and the European Research Council Advanced Grant (GTCMR - 670172) research project of which it is a part.

Global jihadist terrorism differs in important respects from traditional terrorism of the kind practised by the likes of the Irish Republican Army and the Palestinian Liberation Organisation. For one thing, the goals of global jihadism are not simply narrow, nationalistic ones but far more grandiose, notably the establishment of a Caliphate. Moreover, the harmful impact of global jihadist terrorism has been much greater. In its attempts to establish a so-called Caliphate, the terrorism perpetrated by IS has not only hit various Western cities but has also resulted in the deaths of far more people in the Middle East, predominantly among the Muslim population that it claims to represent. Further, there is an important difference in terms of tactics. Elements of the IS Caliphate project that have materialised over the past few years have relied upon a variety of brutal terrorist tactics to subdue and coerce local populations to ensure that they remain under IS control. Finally, global jihadist terrorism has taken a somewhat different organisational form, such as AQ operating 
with franchise groups in a number of locations, including Nigeria, Somalia and Syria.

This volume seeks to provide a single, unified, relatively comprehensive repository of information on jihadist terrorism by offering three sets of integrated chapters organised into three parts. Firstly, four key jihadist terrorist groups (AQ, IS, Hamas and Lashkar-e-Taiba (LeT)); secondly, four zones of armed conflict involving these terrorist groups (Afghanistan, Iraq, Syria and Palestine-Israel); and thirdly, the counter-terrorist responses of five key, liberal democratic states (the United States, United Kingdom, France, Israel and India). Each chapter in a given set complies with a common structure in order to facilitate access to what is, in effect, a reference work on jihadist terrorism. The resulting work is one suitable for use by researchers and students in terrorism studies, by policy-makers, security personnel and others requiring, in particular, a comparative knowledge of counter-terrorism measures across a range of liberal democracies, and by journalists, members of the educated public and others desiring to possess a general understanding of jihadist terrorism and what is being done to combat it.

\section{PART I: TERRORIST GROUPS}

This part provides an in-depth analysis of the four terrorist groups, AQ, IS, Hamas and Lashkar-e-Taiba. A contextual background to each terrorist group is provided, setting the scene for an examination of each chosen organisation. This encompasses: (1) the aims of the group, not only the publicly stated ones but also any 'hidden agendas'; (2) the organisational structure of the group; (3) how the group is financed, how it conducts its training and how it recruits and retains its support base; (4) the higher-level strategies, along with the lower-level tactics of each group.

\section{Chapter 2: ‘Al-Qaeda' by Paul Burke}

With a well-developed capability in recruitment, financing and training, AQ was highly successful in propagating its aims and ideology across the globe, allowing it to grow in numbers, ambition and capability. The ideological foundations of the AQ movement date back to the 13th century and progressed through the interpretations of various individuals, most latterly including Osama bin Laden and Ayman al-Zawahiri. The group spawned a number of regional franchise-style affiliates, such as al-Qaeda in Iraq, led by Abu Musab al-Zarqawi, and al-Qaeda in the Arabian Peninsula, responsible for high-profile attacks such as that against the United States (US) warship, the USS Cole. 


\section{Chapter 3: 'The So-Called Islamic State' by Michael Robillard}

The self-proclaimed Islamic State is a militant Sunni-Salafi-jihadist organisation, operating largely in Iraq, Syria and Libya, whose stated aim is the re-establishment of the Islamic Caliphate of 7th century Islam. The group is a proponent of Sharia law and claims political and theological authority over the world's Muslims. The formation of IS officially occurred in 2013 when its creation was announced by the group's leader, Abu Bakr al-Baghdadi. Its social media campaign, coupled with early military success in Raqqa and Mosul in June 2014, served to attract thousands of foreign fighters to ISIS's ranks. In the last couple of years IS's strength has waned dramatically, in terms of both troop strength and territorial control. A reduced and fractured IS might be even more dangerous in the long run, insofar as the group could decentralise and metastasise into a multiplicity of opportunist terrorist entities, leading to destructive terrorist competition.

\section{Chapter 4: 'Hamas' by Doaa' Elnakhala}

Hamas emerged in the context of the Israeli-Palestinian conflict and despite recent attempts at detaching itself from the Brotherhood, it is considered an offshoot of the Egyptian Muslim Brotherhood. Hamas identifies itself as an Islamic-nationalist liberation movement. Ever since its creation, Hamas has become increasingly influential through its military attacks against Israel, its social and unmatched welfare network at the Palestinian level, and its wide support base. Hamas identifies the liberation of Palestine and the establishment of an Islamic state as its main goals. Hamas has been designated a terrorist organisation by several Western countries due to its employment of terrorism against Israel. In part, the tension between Israel and Hamas lies in the latter's refusal to recognise Israel, although its document from May 2017 demonstrated some changes towards this end. In addition to addressing these issues, this chapter also goes into some detail to cover issues such as Hamas's organisational structure, training and recruitment methods, financing, and strategy and tactics.

\section{Chapter 5: 'Lashkar-e-Taiba' by Anthony Davis}

Lashkar-e-Taiba is all but synonymous with its gunmen's three-day terrorist rampage through Mumbai, India's commercial capital. The global notoriety it achieved in November 2008 with attacks that left 166 dead made it arguably South Asia's best-known terrorist organisation. In addition to a proclivity for high-profile terrorism, LeT has from its earliest beginnings been organised and trained as guerrilla force capable of a range of military operations, undertaken 
most notably in Afghanistan and in the state of Jammu and Kashmir disputed between India and Pakistan. LeT has depended for much of its military capability on its umbilical relationship with the Pakistani military and more specifically the military's intelligence wing, the Inter-Services Intelligence Directorate (ISI). Lashkar's history is best viewed as a careful balancing of two core missions. First has been a commitment to a concept of a globalised jihad aimed at least notionally at the re-institution of the Islamic Caliphate. Second has been dawa, the reformist missionary drive to propagate Ahl-e-Hadith Salafism through proselytising and social welfare outreach within Pakistan and beyond.

\section{PART II: ZONES OF ARMED CONFLICT}

This part examines a number of countries or regions that have suffered from widespread and/or lasting armed conflicts in which terrorism is a major factor. Each chapter begins by outlining the historical context in which the armed conflict in question emerged, including a description of the chief protagonists. The bulk of each chapter deals with the nature of the conflict, for example to what extent it involves conventional warfare. The terrorist and CT strategies and tactics in use are described, as are the results of their use. Finally, an assessment is made of the trajectory of the armed conflict, that is, where it is heading, and what is the likely endpoint.

\section{Chapter 6: 'Afghanistan' by Anthony Davis}

The scourge of terrorism in Afghanistan has emerged from the history of the wars and insurgencies that have devastated the country since 1978. Forty years of unremitting conflict has cost between 1 and 2 million lives and has reflected a geopolitical crisis of a complexity that continues to confound the best efforts of soldiers and diplomats. Since the withdrawal of US combat forces in 2014, the conflict in Afghanistan has escalated sharply. As the Afghan National Defense and Security Forces (ANDSF) have struggled to respond, Taliban forces have extended their footprint across important areas of the country. Against this backdrop, terrorism conducted overwhelmingly in the form of suicide bombings against both military and civilian targets has evolved into a more complex and more lethal element of the broader Taliban insurgency. Since late 2014, the situation has been further exacerbated by the emergence of an IS branch or 'province' (wilayah), the Islamic State Khorasan Province, that has brought them into direct and often bloody conflict with both the ANDSF supported by US airpower and Special Forces, and with the far larger mainstream Taliban. 


\section{Chapter 7: 'Iraq' by Paul Burke}

The Allied invasion of Iraq in 2003 prepared the ground for a vicious, deadly conflict that began as a resistance effort targeting the Allied ground forces, but morphed into a multi-faceted and complex conflict. This involved a range of protagonists and a very fluid and dynamic environment of shifting alliances and changing allegiances, dragging in Sunni and Shia tribes alike, while neighbouring states and other regional actors became increasingly involved in the proxy battleground that Iraq became. This expansive chapter begins with a brief history of Iraq, then moves on to the 1991 invasion and the 2003 invasion, before beginning a detailed description of the complexities of conflict in Iraq that ends with the loss of territory by IS.

\section{Chapter 8: 'Syria' by Michael Robillard}

Following the so-called Arab Spring of 2011, the Assad regime deployed tanks on the streets in May 2011 to suppress protests. While the early stages of the Syrian civil war were initially non-sectarian in nature, the face of the conflict would soon begin to polarise along increasingly sectarian lines as more opportunistic groups, both internally and externally, attempted to exploit the growing power vacuum. In June of 2014, IS's declaration of their self-proclaimed Caliphate brought an influx of thousands of foreign fighters into Syria to join under IS's banner. In September of 2014, the United States and five Arab countries launched air strikes against IS in Raqqa and Aleppo, while in September of 2015, Russia began conducting its first air strikes in Syria, officially stating that it was targeting IS forces. In December 2016, Assad's troops, backed by Russian air power and Iranian-sponsored militias were able to successfully re-take Aleppo and much of Syria. Assad's strategy has resulted in a costly and drawn-out conflict between regime forces and the rebels, with the remainder of the Syrian civilian populace caught in the middle.

\section{Chapter 9: 'Palestine-Israel' by Doaa' EInakhala}

This chapter takes the reader back to the story of the conflict by spanning time from the late 19th century to potential trajectories. Initially, the chapter lays the ground by presenting both the Palestinian and the Israeli claims to the same plot of land. Additionally, it presents the complexity of the conflict by addressing the territorial, the ethnic and the religious dimensions of the conflict. It then addresses major milestones which unravelled along the history of the conflict, such as the Jewish immigration to Palestine, the 1948 and 1967 wars, and the various Israeli military operations. The chapter also provides an overview of the developments experienced by the Israeli occupation, the 
two Palestinian Intifadas and the corresponding evolution of the Israeli and Palestinian strategies and tactics. The complexity of the conflict is again illustrated in the multiplicity of local, regional and international actors. Finally, the chapter sheds light on potential paths that could be followed by the conflict, including a democratic bi-national state, an undemocratic discriminatory bi-national state, and a two-state project.

\section{PART III: NATIONAL COUNTER-TERRORISM RESPONSES}

This part examines the variety of ways in which key liberal democratic states have responded to terrorism. Each chapter focuses on a single nation-state and examines: (1) what actual and potential terrorist threats are faced by the nation-state in question; (2) what legislative instruments have been introduced as mechanisms for dealing with terrorist-related offences; (3) what is the institutional architecture, including key security agencies such as police, military and intelligence agencies, for combating terrorism, and how have they evolved or been re-designed in the face of the jihadist terrorist threat; (4) what is the overarching CT strategy and key CT tactics, including de-radicalisation and social media policies.

Some of the selected countries, such as Israel, India and the United Kingdom (UK), have faced long-term terrorism problems (for example, the activities of the Irish Republican Army, IRA) that have spanned multiple decades. These have had a historic bearing on previous approaches to the criminalisation of terrorism-related offences, sentencing and the management of convicted terrorists, in prison as well as post-release. For other countries such as the United States, terrorism, and jihadist terrorism in particular, is a relatively new problem. Moreover, it is important to distinguish between CT strategies and tactics in zones of armed conflict and those in well-ordered jurisdictions, such as London, Paris and New York. It is also important to take into account the nature of local grievances that might be exploited by terrorist groups, and to frame CT strategies accordingly.

\section{Chapter 10: 'National Counter-Terrorism Responses: United States of America' by Michael Robillard}

The 9/11 attacks radically shifted US counter-terrorism strategy from a fundamentally reactive to mainly preventive posture, both at home and abroad. This resulted in significant re-structuring and re-defining of purposes for many US domestic and Department of Defense agencies, as well as a critical re-thinking of the post-9/11 threat picture and overall operational environment. This move to a preventive, warfighting and counter-terrorist strategy posture can best be 
seen in the subsequent US-led invasions of Afghanistan in 2001 and Iraq in 2003. As the Bush administration wound down and handed off authority to the Obama administration, US counter-terrorism strategy shifted along with the terrorism threat picture. While the Bush administration's counter-terrorism strategy will likely be most remembered for its emphasis on 'boots on the ground' and detention, the Obama administration will probably be remembered for its significant drawdown of troop presence in both Afghanistan and Iraq, a drawdown of detainees at Guantanamo, and its heightened emphasis on the use of targeted drone strikes and special operations raids.

\section{Chapter 11: 'National Counter-Terrorism Responses: United Kingdom' by Paul Burke}

The historical basis of the United Kingdom's approach to dealing with terrorism is derived in large part from the country's experience in dealing with the issues arising from Irish and Northern Irish movements in the 20th century. The contemporary threat of international terrorism created a shift in thinking in the UK's approach, to both the conceptual nature of terrorism and also how to legislate for countering this threat. Successive laws have countered threats such as recruitment, radicalisation, facilitation and even 'glorification', while the police, intelligence and security agencies have had to adapt their methods and their organisational structures for a more collaborative approach as part of the UK's counter-terrorism strategy known as CONTEST.

\section{Chapter 12: 'National Counter-Terrorism Responses: France' by Doaa' EInakhala}

Today, France is listed among the top targets of terrorism, especially that carried out by IS. The terrorist threat in France emanates from both internal and external terrorist operatives, such as those involved in the Franco-Belgian terrorist networks, foreign fighters returning from Syria and Iraq, and lone wolves. Radicalisation all around the French Republic has been also on a remarkable rise. Overall, France deals with terrorism within the confines of its criminal justice code. This chapter also examines the most important counter-terrorism institutions active today, including the police, the National Gendarmerie, the intelligence community and the military. Over time, the French counter-terrorism strategy has evolved from prevention to accommodation to suppression. Despite heavy reliance on suppression, the current French strategy also has preventive elements. Finally, this chapter summarises the French counter-terrorism tactics, including collecting intelligence, combating radicalisation, military deployments, fighting terrorist propaganda, the action plan against terrorism, and so on. 


\section{Chapter 13: 'National Counter-Terrorism Responses: Israel' by Doaa' Elnakhala}

Since the creation of the State of Israel, it has been subjected to attacks by non-state actors, mostly orchestrated by Palestinians who were displaced due to the creation of the State of Israel. Today, Israel has developed a rather complex legal and institutional design to respond to these threats. The Israeli counter-terrorism laws and practices were either inherited from the British Mandate Palestine or later developed by the state. Today, the main source of threat faced by Israel emanates from Palestinian militant groups, but Hamas has become the most efficient and resourceful at inflicting harm on Israel. The overall Israeli counter-terrorism strategy is to deter terrorism. Over time, Israel has employed a rather long list of tactics that are meant to serve this strategy, including home-demolition, invasions, separation, checkpoints and closures, assassinations, detention, and involving Israeli civilians in counter-terrorism. In the midst of this, Israel has become a leading actor in the global area of military technology.

\section{Chapter 14: 'National Counter-Terrorism Responses: India' by Anthony Davis}

India's primary terrorist threat remains, as it has been since the turn of the century, the jihadist challenge. Over recent years this has evolved into an essentially three-pronged phenomenon: cross-border fedayeen-style attacks carried out by groups such LeT and Jaish-e-Mohammed (JeM, Army of Muhammad); terror attacks, typically bombings, by disaffected Indian Muslim (IM) youth; and disaffected Muslim self-starters inspired by IS's global call for attacks on targets of opportunity. In recent decades India has struggled to devise a comprehensive legal framework for its counter-terrorist response. In a response shaped by the legacy of British colonialism, India's default framework has been to deal with terrorist acts as criminal offences to be handled by state police forces. The terrorist threat has often spilled into protracted insurgency situations that have overwhelmed the capacity of state police and demanded the intervention of Central Armed Police Forces and the national military. These circumstances have resulted in the enactment or repeal of several important legislative platforms drawn up specifically to meet the challenge of terrorism. 